\title{
Photophysiology of the marine cyanobacterium Synechococcus sp. WH8102, a new model organism
}

\author{
C. Six ${ }^{1}$, J. C. Thomas ${ }^{2}$, B. Brahamsha ${ }^{3}$, Y. Lemoine ${ }^{4}$, F. Partensky ${ }^{1, *}$ \\ ${ }^{1}$ Station Biologique, UMR 7127 CNRS et Université Pierre et Marie Curie, Place Georges Tessier, 29682 Roscoff cedex, France \\ ${ }^{2}$ Ecole Normale Supérieure, FRE 2433 'Organismes Photosynthétiques et Environement', 46 rue d'Ulm, \\ 75230 Paris cedex 05, France \\ ${ }^{3}$ Marine Biology Research Division, Scripps Institution of Oceanography, University of California San Diego, Gilman Drive, \\ La Jolla, California 92093-0202, USA \\ ${ }^{4}$ Equipe de Cytophysiologie végétale et Phycologie, UPRES-A CNRS 8013 ELICO (Ecosystèmes Littoraux et Côtiers), \\ Université des Sciences et Technologie de Lille, Cité Scientifique, Bâtiment SN2, 59655 Villeneuve d'Asq, France
}

\begin{abstract}
Synechococcus spp. constitute a major and ubiquitous component of marine ecosystems. The genome of one strain of this genus, WH8102, has recently been completely sequenced. Since it can also be genetically manipulated, this clone has the potential to become a new model organism; however, to date, it remains poorly characterised in terms of pigment composition, optical properties and photophysiology. It has a very high phycourobilin to phycoerythrobilin (PUB:PEB) ratio (ca. 1.95 at low light), and is therefore representative of Synechococcus populations found in oligotrophic areas of the ocean. We show here that this strain has a very wide growth irradiance range from $<15$ to $>650 \mu \mathrm{mol}$ photons $\mathrm{m}^{-2} \mathrm{~s}^{-1}$ continuous white light, with a maximum growth rate $\left(\mu_{\max }=1.13 \pm\right.$ $\left.0.02 \mathrm{~d}^{-1}\right)$ at $207 \mu \mathrm{mol}$ quanta $\mathrm{m}^{-2} \mathrm{~s}^{-1}\left(I_{\max }\right)$. As cells acclimated to high light, drastic variations in the chlorophyll a (chl a), $\beta$-carotene and phycoerythrin (PE) contents were observed, reaching a quasi steady state around $I_{\max }$. In contrast, the zeaxanthin content remained approximately constant whatever the light level. Similarly, the carbon and nitrogen contents did not significantly vary with irradiance. Red and orange fluorescences, as measured by flow cytometry, were found to correlate well with chl $a$ and PE contents, respectively. Spectrometric analyses of phycobilisome (PBS)-containing fractions from cells grown under different photon fluxes suggest a specific reduction of the PEII content relative to other phycobiliproteins (PBPs) during acclimation of the PBSs to high light.
\end{abstract}

KEY WORDS: Synechococcus - Marine cyanobacteria - Photoacclimation - Light stress · Phycobilisomes $\cdot$ Pigment content $\cdot \mathrm{C}: \mathrm{N}$ ratio $\cdot$ Flow cytometry

Resale or republication not permitted without written consent of the publisher

\section{INTRODUCTION}

Synechococcus spp. are small unicellular coccoid cyanobacteria found in very different habitats such as fresh waters, hot springs, and coastal and oceanic waters. Phylogenetic studies however reveal that species belonging to this assemblage are fairly dispersed within the cyanobacterial radiation, and therefore that Synechococcus does not correspond to a true genus (Urbach et al. 1998, Herdman et al. 2001). Still, most 'true' oceanic Synechococcus strains (i.e. those with an obligate requirement for elevated salt concentrations) isolated to date are gathered in 16S rRNA trees within a monophyletic branch, recently designated the ' 5.1 cluster' (Herdman et al. 2001). All strains within this cluster (previously named 'marine cluster A'), but for a small group (see Fuller et al. 2003), possess C-phycoerythrin (PE) as the major light-harvesting pigment. PE confers a bright orange autofluorescence on oceanic Synechococcus strains, a peculiarity which renders them easy to visualise by fluorescence microscopy or flow cytometry. Many ecological studies using these techniques have demonstrated that PE-containing Synechococcus cells (i.e. probable representatives of the 5.1 cluster) are pre- 
sent oceanwide from coastal to pelagic waters and from the equator to high latitudes (Olson et al. 1990, Partensky et al. 1999a, Liu et al. 2002). Thus, this cluster appears to be remarkably ubiquitous, even more so than its most closely related group in phylogenetic trees, the Prochlorococcus genus, the distribution of which is restricted to low latitudes (0 to $40^{\circ} \mathrm{N} / \mathrm{S}$; Partensky et al. 1999b). Synechococcus abundances are often elevated in nutrient-rich coastal or mesotrophic waters (typically $10^{4}$ to $10^{5}$ cells $\mathrm{ml}^{-1}$ ), but decrease dramatically in nutrient-poor pelagic waters. In contrast, Prochlorococcus cells are often as abundant in oligotrophic as mesotrophic waters although it may be scarce or even absent in upwelling or river-influenced coastal waters (Partensky et al. 1996, Shalapyonok et al. 2001, Jiao et al. 2002). A number of studies indicate that when the water column is stratified, Prochlorococcus cells can occupy a deeper layer than do Synechococcus cells (see Partensky et al. 1999a, b for reviews). It has clearly been shown that the large vertical distribution of Prochlorococcus was due to the occurrence of several genotypes (often called 'ecotypes') adapted to different light niches (Moore et al. 1998, Moore \& Chisholm 1999, West \& Scanlan 1999), but whether such a phenomenon of light niche partitioning also occurs for marine Synechococcus is less clear (Ferris \& Palenik 1998, Fuller et al. 2003, Scanlan 2003, Toledo \& Palenik 2003). This question can only be solved by studying the individual photophysiological properties of representative PEcontaining Synechococcus strains. To date, only very few marine Synechococcus spp. have been characterised in this respect, including strains WH7803 (Kana \& Glibert 1987a,b, Kana et al. 1988) and WH8103 (Moore et al. 1995). One obvious additional candidate for such a study is Synechococcus sp. WH8102, the genome of which has been fully sequenced by the Joint Genome Institute (Palenik et al. 2003). This strain, a member of the 5.1 cluster, was selected for genome sequencing mainly because it can be genetically manipulated (Brahamsha 1996a) and because of its swimming ability (Brahamsha 1996b); however, to date, it remains poorly characterised in terms of pigment composition, optical properties and photophysiology, an issue that we address in the current paper.

Phycobilisomes (PBSs) of marine Synechococcus have a number of specificities with regard to other cyanobacteria (Ong et al. 1984, Ong \& Glazer 1987, 1991, Swanson et al. 1991, Wilbanks et al. 1991). The phycobiliprotein (PBP) constituting the core of PBSs (allophycocyanin [APC]) is well conserved both at the structural level and by the type of chromophore (PB) it binds (phycocyanobilin [PCB]). Phycocyanin (PC) which constitutes the base of the rods is more specific and has been designated as R-PC class II (hereafter PCII; Ong \& Glazer 1987) since, besides PCB (the only chromophore found associated to PC in freshwater species), it also binds phycoerythrobilin (PEB). However, the diversity of PC has only been studied in a few strains of the marine Synechococcus cluster 5.1 and whether presence of PCII is a general feature of this group remains to be checked. Another peculiarity so far only observed in the PBS of marine Synechococcus spp. is that the rod extremities are constituted by 2 structurally different forms of PE (PEI and PEII; Ong \& Glazer 1991) instead of one as in other PE-containing cyanobacteria. PEII binds both PEB and phycourobilin (PUB). PEI binds either PEB alone (e.g. in strains WH7803 and WH8020) or both PEB and PUB (e.g. in strain WH8103), but, in the latter case, PEI binds fewer PUB molecules than does PEII (Ong \& Glazer 1991). The total PUB:PEB ratio exhibits strong variations among PE-containing marine Synechococcus strains (Waterbury et al. 1986), resulting in wide variations in the optical properties and colour of cultures (from red to orange). Since PUB and PEB maximally absorb at ca. 495 and $545 \mathrm{~nm}$, respectively (Ong et al. 1984), variations in the relative composition of these 2 chromophores allow species of this genus to adapt to the wide range of light qualities naturally occurring in the marine environment. It has been clearly established that high PEB cells are predominant in green waters (i.e. coastal or mesotrophic areas), whereas the high PUB cells dominate in blue offshore waters (Olson et al. 1990, Lantoine \& Neveux 1997, Wood et al. 1998, 1999, Sherry \& Wood 2001). Whether changes in PUB:PEB ratios occur over vertical light gradients is more controversial. Using microphotometry on individual Synechococcus cells from the Sargasso Sea, Campbell \& Iturriaga (1988) found no significant variation with depth of the PUB:PEB ratio estimated from the ratio of fluorescence emissions at $575 \mathrm{~nm}$ measured after excitation at 490 and $543 \mathrm{~nm}$. Using a flow cytometric method to assess the PUB:PEB ratio (i.e. the ratio of orange fluorescence emissions resulting from laser excitation at 488 and $515 \mathrm{~nm})$, Olson et al. (1988, 1990) also observed no clear trend of this ratio as a function of irradiance on both isolates and natural samples. In contrast, using spectrofluorimetry, Lantoine \& Neveux (1997) did observe some variations of the PUB:PEB fluorescence excitation ratio with depth at 2 stations of the tropical NE Atlantic ocean, but because high and low PUB Synechococcus populations cooccurred at both stations, they could not unambiguously relate their observations to physiological processes. The extent of light-induced changes in the PUB:PEB ratio within a given genotype has been little explored to date, or only over a limited light gradient (see e.g. Palenik 2001). More generally, the mechanisms involved in the acclimation of Synechococcus to different growth irradiances or light climates are still 
barely known in these organisms. Determining the extent of the plasticity of the photosynthetic apparatus of representative individual strains is however critical for correctly interpreting or calibrating measurements performed on natural populations, such as flow cytometric or HPLC pigment analyses. To better understand photoacclimation processes in marine Synechococcus cyanobacteria, we studied the effects of different growth irradiances and light qualities on growth, cell and PBS pigment content as well as optical properties. For the present work, we mainly used the high PUB clone Synechococcus sp. WH8102, which since (1) its genome has been totally sequenced, (2) it can be genetically manipulated, and (3) it is representative of a group with major ecological significance will likely become a new model organism. For comparison, some measurements have also been carried out on 3 strains with different PUB contents (WH8103, WH7803 and Minos01).

\section{MATERIALS AND METHODS}

Culture conditions. The marine Synechococcus sp. clone WH8102 was grown in either $50 \mathrm{ml}$ polystyrene culture flasks (Sarsted) or $1 \mathrm{l}$ polycarbonate flasks (Nalgene) containing $0.2 \mu \mathrm{m}$ filtered $\mathrm{SN}$ medium (Waterbury et al. 1986). Three replicate batch cultures were maintained at ca. $24 \pm 1^{\circ} \mathrm{C}$ under continuous white light provided by 12 Sylvania Daylight 58W/154 fluorescent tubes. For comparison of selected parameters, 3 other marine Synechococcus spp. clones (WH7803, WH8103 and Minos01) were also grown under the same conditions. The origin of all 4 strains is described in Fuller et al. (2003). Cells were progressively adapted for at least $3 \mathrm{wk}$ to 8 different continuous white irradiances ranging from 15 to $650 \mu \mathrm{mol}$ photons $\mathrm{m}^{-2} \mathrm{~s}^{-1}$ obtained using various combinations of density and/or diffusion filters (LEE Filters, Panavision). Irradiances were measured in water with a LICOR (LI-1000) quantameter equipped with a spherical probe (LI-COR SPQA).

The eventual ability of Synechococcus spp. strains to perform chromatic acclimation was studied by growing them under 3 different light qualities, i.e. bluegreen, green and red, using coloured filters (LEE Filters \#183, \#139 and \#106, respectively). For better intercomparison, the irradiance level within the cultures was adjusted to $25 \mu \mathrm{mol}$ photons $\mathrm{m}^{-2} \mathrm{~s}^{-1}$.

Growth rates and flow cytometric parameters. Aliquots of cultures grown under different light conditions were taken daily and preserved in $0.2 \%$ glutaraldehyde grade II (Sigma), frozen in liquid nitrogen and stored at $-80^{\circ} \mathrm{C}$. Cell concentrations were determined using a flow cytometer (FACSort, Becton
Dickinson) for which laser emission is set at $488 \mathrm{~nm}$. The flow rate was about $30 \mu \mathrm{min}^{-1}$ and the sheath fluid was filtered seawater diluted with $25 \%$ Milli-Q water as for the SN medium. Growth rates $\left(\mu\right.$ in $\left.\mathrm{d}^{-1}\right)$ were computed as the slope of a $\mathrm{Ln}(\mathrm{N} t)$ vs time plot, where $\mathrm{N} t$ is cell number at time $t$. The theoretical irradiance at which no growth occurs $\left(I_{\text {comp }}\right)$ was extrapolated from the $x$-intercept for a linear fit to the lightlimited region of the $\mu$ vs log $(I)$ plot.

Flow cytometric parameters including right-angle light scatter (RALS), orange $(585 \pm 21 \mathrm{~nm})$ and red $(>650 \mathrm{~nm})$ fluorescences were normalised with standard $0.95 \mu \mathrm{m}$ YG beads (Polysciences) after analysing list mode files with the custom-designed freeware CYTOWIN (Vaulot 1989). The forward angle light scatter (FALS) signal proved too wide to be exploited. Cells were also stained using a 1:10000 dilution of a commercial solution of SYBR Green I (Molecular Probes), as previously described (Marie et al. 1999) to check for bacterial contamination.

Pigment analyses. The chlorophyll $a(\mathrm{chl} a)$ and carotenoid cell concentrations were determined for each culture after methanolic extraction using a HPLC Hewlett Packard 1100 system equipped with a $\mathrm{C}_{18}$ col-

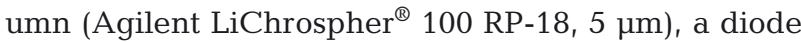
array detector and quaternary pump system HP1100.

A known number of cells was harvested and resuspended in $1 \mathrm{ml}$ extraction solvent $(0.01 \mathrm{M}$ ammonium acetate in methanol) and sonicated (Ultrasonic Processor 50) with rapid pulses at $50 \mathrm{~W}$ in the dark at $4^{\circ} \mathrm{C}$. All following manipulations were carried out under these conditions. After a $2 \mathrm{~h}$ incubation under $\mathrm{N}_{2}$ atmosphere and strong vortexing, the extract was centrifuged for 12 min at $19400 \times g$ and the supernatant was filtered on a $0.2 \mu \mathrm{m}$ filter (Sartorius Minisart). Absorption spectra of the pigment extracts were then recorded with a double beam spectrophotometer (UV/Vis UVIKON 943) and normalised at $665 \mathrm{~nm}$ (red chl a maximum). A $100 \mu \mathrm{l}$ aliquot of the methanol extract was injected in the HPLC system in the presence of lycopene as an internal standard. Pigments were separated in reversed phase with the solvent gradient adjusted as described by Wright \& Jeffrey (1997). The apparatus response was previously calibrated with pure standard pigments (all from Sigma Aldrich but zeaxanthin from Extrasynthese). Chromatograms were monitored with the software HP ChemStation (Hewlett Packard).

For extracting PBSs and estimating PE concentrations, cells were resuspended in $1 \mathrm{ml} 0.75 \mathrm{M}$ phosphate buffer $\left(60 \% \mathrm{~K}_{2} \mathrm{HPO}_{4}, 40 \% \mathrm{NaH}_{2} \mathrm{PO}_{4}\right)$ and sonicated in the dark at $4{ }^{\circ} \mathrm{C}$ in the presence of $1 \mathrm{mM}$ antiprotease cocktail (benzamidine, phenylmethylsulfonyl fluorure and $\varepsilon$-amino-n-caproic acid; all from Sigma Aldrich). Use of such a high ionic strength buffer allowed the integrity of PBS particles to be well preserved, which 
in these conditions retain all PBPs and their linker polypeptides and remain energetically connected, as was checked by biochemical and optical analyses (data not shown). After a 20 min incubation and strong vortexing, the aqueous extract was centrifuged for $12 \mathrm{~min}$ at $19400 \times g$. The supernatant was then centrifuged for $1 \mathrm{~h}$ at $130000 \times g$ at $4^{\circ} \mathrm{C}$ in a Beckman XL-70 ultracentrifuge in order to eliminate any traces of chl $a$. Absorption spectra were then recorded. The PUB:PEB, PUB:PCB and PEB:PCB ratios were calculated using the optical densities at 492, 543 and $640 \mathrm{~nm}$, which are the major absorption maxima of PUB, PEB and PCB at low light, respectively (see below). The extraction procedure was applied a second time and the 2 supernatants were pooled. PE concentration was assessed from these PBS-enriched fractions with a double beam spectrophotometer (UV/Vis UVIKON 943) using an extinction coefficient at $492 \mathrm{~nm}$ of $2.78 \times 10^{6} \mathrm{M}^{-1} \mathrm{~cm}^{-1}$ (Ong et al. 1984) and the molecular weight (240 kDa) of PEII estimated by Ong \& Glazer (1991) for Synechococcus sp. WH8103, a high PUB strain phylogenetically closely related to WH8102 (Fuller et al. 2003). This method somewhat underestimates the total PE pool for several reasons. First, presence of linkers may influence the extinction coefficient of PBPs (Glazer 1985, 1989). Second, our PBS preparations also contained PEI, which besides PEB also binds PUB, although to a lesser extent than does PEII (data not shown). And third, despite a second extraction step which increases the yield of PBS particles, this yield was likely lower than $100 \%$, since PBS are notoriously difficult to extract. Because of these limitations, the absolute cell PE contents reported in Table 1 are only semi-quantitative.

Carbon and nitrogen measurements. Cells were filtered on $25 \mathrm{~mm}$ GF/F filters previously burnt for $5 \mathrm{~h}$ at $500^{\circ} \mathrm{C}$ in an oven (Thermolyne Sybron, type 6000 furnace) to remove any trace of organic matter. Caution was taken to avoid any contamination during filtration. Samples were immediately frozen at $-80^{\circ} \mathrm{C}$ until analysis. Carbon and nitrogen concentrations were determined using a NA2100 Protein analyser (CE Instrument) after calibration with an Orchard Leave standard $(49.17 \%$ C, $2.38 \% \mathrm{~N})$. Values were corrected from the signal induced by the filters and the tin capsules.

Our cultures were slightly contaminated by one small homogeneous bacterial population, as determined by flow cytometry, after DNA staining, from its narrow DNA fluorescence and RALS distribution peaks which were similar in all samples. After its concentration was accurately determined, we corrected the C and N contents of Synechococcus cells (hereafter $\mathrm{Cs}$ and Ns, respectively) by subtracting the bacterial $\mathrm{C}$ and $\mathrm{N}$ assuming $20 \mathrm{fg} \mathrm{C}$ and $5.6 \mathrm{fg} \mathrm{N}$ per bacterial cell (Lee \& Fuhrman 1987, Liu et al. 1999).
In vivo absorption spectra. After concentrating cultures in exponential phase by gentle centrifugation $(6000 \times g$ for $10 \mathrm{~min})$, in vivo absorption spectra were recorded with a double wavelength spectrophotometer (Aminco Chance, model DW2). Spectra were recorded between 400 and $750 \mathrm{~nm}$ at a $0.5 \mathrm{~nm}$ resolution and a speed of $120 \mathrm{~nm} \mathrm{~min}{ }^{-1}$. The optical density at $750 \mathrm{~nm}\left(A_{750}\right)$ can be used as an index of cell concentration (Duke et al. 1989). Absorbance indexes on a per cell number basis were calculated at each growth irradiance for chl $a$, PUB and PEB, as follows:

$$
\begin{aligned}
I_{\text {chl } a} & =\left(A_{680}-A_{750}\right) / A_{750} \\
I_{\text {PUB }} & =\left(A_{492}-A_{750}\right) / A_{750} \\
I_{\text {PEB }} & =\left(A_{543}-A_{750}\right) / A_{750}
\end{aligned}
$$

where $A_{\lambda}$ is the absorption at wavelength $\lambda(\mathrm{nm})$. Such indexes give an indication of the quantity per cell of a given pigment in a sample culture. The blue to red ratio (B:R; Mitchell \& Kiefer 1988) was calculated by dividing the absorption values at 437 and $680 \mathrm{~nm}$.

Fluorescence measurements at room temperature. Cells from an exponential phase culture were incubated for several minutes in the dark. Then, in vivo fluorescence spectra at room temperature were recorded in a quartz cuvette with a Perkin Elmer LS50B spectrofluorimeter equipped with a red sensitive photomultiplier. Spectra were monitored with the Perkin Elmer FL WinLab software using the correction mode for excitation. Emission spectra were recorded between 530 and $750 \mathrm{~nm}$ with an excitation at $492 \mathrm{~nm}\left(\lambda_{\max }\right.$ absorption of PUB) and excitation spectra between 420 and $550 \mathrm{~nm}$ with an emission wavelength at $566 \mathrm{~nm}$ ( $\lambda_{\max }$ emission of PE). Both spectra were recorded at $150 \mathrm{~nm} \mathrm{~min}{ }^{-1}$ and the slits were fixed at $7.0 \mathrm{~nm}$. Fluorescence emission spectra were then normalised at the PC emission maxima for comparison.

\section{RESULTS}

\section{Growth rate}

Synechococcus WH8102 was successfully grown over a wide range of growth irradiance (from 15 to $650 \mu \mathrm{mol}$ photons $\mathrm{m}^{-2} \mathrm{~s}^{-1}$ continuous white light) after cells were progressively acclimated to higher irradiance by ca. $2 \times$ increase steps (Table 1 ). Sharp transitions ( $\geq 5$ to $6 \times$ ) from low to high growth irradiance generally led to photoinhibition of cell growth and death of the major part of the population. Furthermore, even when adapted to high light, cultures collapsed rapidly once they had reached their maximal yield, whereas under low light they could remain in stationary phase for several weeks (data not shown). The 
maximum growth rate $\left(\mu_{\max }=1.13 \pm 0.02 \mathrm{~d}^{-1}\right)$ was reached at $207 \mu \mathrm{mol}$ photons $\mathrm{m}^{-2} \mathrm{~s}^{-1}\left(I_{\max }\right)$ and was more than 2 times higher than at $15 \mu$ mol photons $\mathrm{m}^{-2} \mathrm{~s}^{-1}$. Three other marine Synechococcus strains (WH7803, WH8103 and Minos01) were also successfully grown over the same light gradient (15 to $650 \mu \mathrm{mol}$ photons $\mathrm{m}^{-2} \mathrm{~s}^{-1}$ ) and all grew faster at high than at low light, although their growth rates were not precisely measured (but see Kana \& Glibert 1987a and Moore et al. 1995 for the first 2 strains, respectively).

Comparison of growth rates of Synechococcus sp. WH8102 under different light qualities at a fixed growth irradiance of $25 \mu \mathrm{mol}$ photons $\mathrm{m}^{-2} \mathrm{~s}^{-1}$ shows that blue-green light is optimal for growth $(\mu=0.72 \pm$ $\left.0.03 \mathrm{~d}^{-1}\right)$ followed by white $\left(\mu=0.62 \pm 0.03 \mathrm{~d}^{-1}\right)$, green $\left(\mu=0.41 \pm 0.07 \mathrm{~d}^{-1}\right)$ and red light $\left(\mu=0.28 \pm 0.06 \mathrm{~d}^{-1}\right.$; $\mathrm{n}=2$ ).

\section{Pigment content}

HPLC analysis revealed the occurrence of only 3 major pigments in methanolic extracts identified as zeaxanthin, chl $a$ and $\beta$-carotene, as classically observed in marine Synechococcus (see e.g. Kana et al. 1988). Chl $a$ and $\beta$-carotene cell contents showed a similar decrease with growth irradiance (Table 1), so their variations were correlated $([\beta-\mathrm{car}]=0.023[\mathrm{chl} a]$ $+0.093 ; \mathrm{r}^{2}=0.87, \mathrm{n}=8$ ). They both reached a quasi steady state of about $0.6 \mathrm{fg} \mathrm{cell}^{-1}$ for chl $a$ and $0.1 \mathrm{fg}$ cell $^{-1}$ for $\beta$-carotene around $200 \mu \mathrm{mol}$ photons $\mathrm{m}^{-2} \mathrm{~s}^{-1}$, i.e. at the optimal irradiance for growth $\left(I_{\max }\right)$. In contrast, the zeaxanthin cell content did not significantly change with irradiance $\left([\mathrm{zea}]_{\mathrm{avg}}=1.07 \pm 0.16 \mathrm{fg} \mathrm{cell}^{-1}\right.$; Table 1). Consequently, the zeaxanthin:chl a ratio showed an exponential increase with increasing irradiances from about 0.11 at $15 \mu \mathrm{mol}$ photons $\mathrm{m}^{-2} \mathrm{~s}^{-1}$ to 1.42 at $650 \mu \mathrm{mol}$ photons $\mathrm{m}^{-2} \mathrm{~s}^{-1}$ (Table 1).
Although being semi-quantitative (see 'Materials and methods'), measurements of the cell PE content clearly point out the strong variation of this pigment occurring in response to increasing growth irradiances (i.e. a ca. 20 -fold decrease from 15 to $650 \mu \mathrm{mol}$ photons $\mathrm{m}^{-2} \mathrm{~s}^{-1}$; Table 1).

\section{Carbon and nitrogen content}

Notwithstanding the presence of one small bacterial contaminant in our cultures, the $\mathrm{C}$ and $\mathrm{N}$ contents of Synechococcus WH8102 could reasonably be assessed after accurate counting of Synechococcus and bacterial cells by flow cytometry. Despite some scatter in our data set, it appears that the elemental composition of Synechococcus WH8102 does not significantly vary with increasing irradiances (Table 1). Its $\mathrm{C}$ content (Cs) averaged $279.1 \pm 84.2 \mathrm{fg} \mathrm{cell}^{-1}$ and its $\mathrm{N}$ content $(\mathrm{Ns})$ averaged $70.8 \pm 20.9$. The mean Cs:Ns ratio was $4.59 \pm$ 0.31 (mol:mol) and was not significantly different from the $\mathrm{C} t$ :N $t$ ratio measured for the whole cultures, including the contaminant bacteria $(4.52 \pm 0.22 ; \mathrm{mol}: \mathrm{mol})$.

\section{Flow cytometric parameters}

Cultures of Synechococcus sp. WH8102 grown under low and high photon flux densities displayed very different flow cytometric signatures (bi-parametric cytograms not shown). These differences were mainly attributable to dramatic variations in relative red fluorescence (RF) and orange fluorescence per cell (OF) which decreased by 90 and $75 \%$, respectively, between 15 and $650 \mu \mathrm{mol}$ photons $\mathrm{m}^{-2} \mathrm{~s}^{-1}$ (Fig. 1A). RF was strongly correlated to chl a content and the relation was linear over the whole range of growth irradiances $(\mathrm{RF}=$ $1.25[\mathrm{chl} a]+1.46 ; \mathrm{r}^{2}=0.96, \mathrm{n}=8$ ). OF showed a lower

Table 1. Synechococcus sp. WH8102. Variations of growth rate $(\mu)$, carbon (Cs), nitrogen (Ns) and pigment content (chl a, zeaxanthin, $\beta$-carotene and phycoerythrin) and ratios of cells grown over a range of continuous white irradiances ( $\mathrm{n}=3$ except for phycoerythrin for which $\mathrm{n}=2$ ); nd = no data

\begin{tabular}{|c|c|c|c|c|c|c|c|c|c|}
\hline $\begin{array}{l}\text { Irradiance } \\
(\mu \mathrm{mol} \\
\text { photons } \\
\mathrm{m}^{-2} \mathrm{~s}^{-1} \text { ) }\end{array}$ & $\begin{array}{c}\mu \\
\left(d^{-1}\right)\end{array}$ & $\begin{array}{c}\text { Cs } \\
\left(\text { fg cell }^{-1}\right)\end{array}$ & $\begin{array}{c}\mathrm{Ns} \\
\left(\mathrm{fg} \mathrm{cell}^{-1}\right)\end{array}$ & $\begin{array}{c}\text { Cs:Ns } \\
\text { (mol:mol) }\end{array}$ & $\begin{array}{c}\text { Chl a } \\
\left(\text { fg cell }^{-1}\right)\end{array}$ & $\begin{array}{l}\text { Zeaxanthin } \\
\left(\text { fg cell }^{-1}\right)\end{array}$ & $\begin{array}{l}\beta \text {-carotene } \\
\left(\text { fg cell }^{-1}\right)\end{array}$ & $\begin{array}{c}\text { Phyco- } \\
\text { erythrin } \\
\left(\text { fg cell }^{-1}\right)\end{array}$ & $\begin{array}{c}\text { Zeax.: } \\
\text { chl a } \\
\text { (mol:mol) }\end{array}$ \\
\hline 15 & $0.52 \pm 0.01$ & $323.8 \pm 0.1$ & $90.2 \pm 2.6$ & $4.19 \pm 0.12$ & $5.71 \pm 0.73$ & $0.94 \pm 0.21$ & $0.21 \pm 0.02$ & $91.02 \pm 9.41$ & 0.10 \\
\hline 25 & $0.61 \pm 0.06$ & $192.5 \pm 3.4$ & $50.9 \pm 2.9$ & $4.43 \pm 0.32$ & $4.05 \pm 0.91$ & $0.94 \pm 0.09$ & $0.20 \pm 0.10$ & $42.89 \pm 22.27$ & 0.14 \\
\hline 50 & $0.72 \pm 0.03$ & nd & nd & nd & $1.47 \pm 1.01$ & $1.13 \pm 0.21$ & $0.15 \pm 0.09$ & $49.97 \pm 3.48$ & 0.54 \\
\hline 86 & $0.94 \pm 0.06$ & $147.8 \pm 7.5$ & $40.5 \pm 2.4$ & $4.27 \pm 0.45$ & $0.90 \pm 0.32$ & $0.92 \pm 0.28$ & $0.08 \pm 0.02$ & $15.64 \pm 1.73$ & 0.58 \\
\hline 207 & $1.13 \pm 0.02$ & $344.1 \pm 6.3$ & $82.9 \pm 3.7$ & $4.85 \pm 0.15$ & $0.59 \pm 0.27$ & $0.99 \pm 0.48$ & $0.12 \pm 0.03$ & $10.30 \pm 0.39$ & 0.87 \\
\hline 445 & $1.04 \pm 0.08$ & $257.6 \pm 0.6$ & $61.7 \pm 2.9$ & $4.88 \pm 0.22$ & $0.61 \pm 0.14$ & $1.33 \pm 0.73$ & $0.09 \pm 0.05$ & $7.73 \pm 1.61$ & 1.21 \\
\hline 550 & $0.86 \pm 0.03$ & $380.4 \pm 15.1$ & $97.1 \pm 8.4$ & $4.60 \pm 0.55$ & $0.65 \pm 0.01$ & $1.26 \pm 0.35$ & $0.12 \pm 0.03$ & nd & 1.24 \\
\hline 650 & $0.89 \pm 0.04$ & $307.4 \pm 17.6$ & $72.6 \pm 2.6$ & $4.94 \pm 0.16$ & $0.46 \pm 0.09$ & $1.03 \pm 0.18$ & $0.10 \pm 0.10$ & $5.36 \pm 0.99$ & 1.42 \\
\hline
\end{tabular}



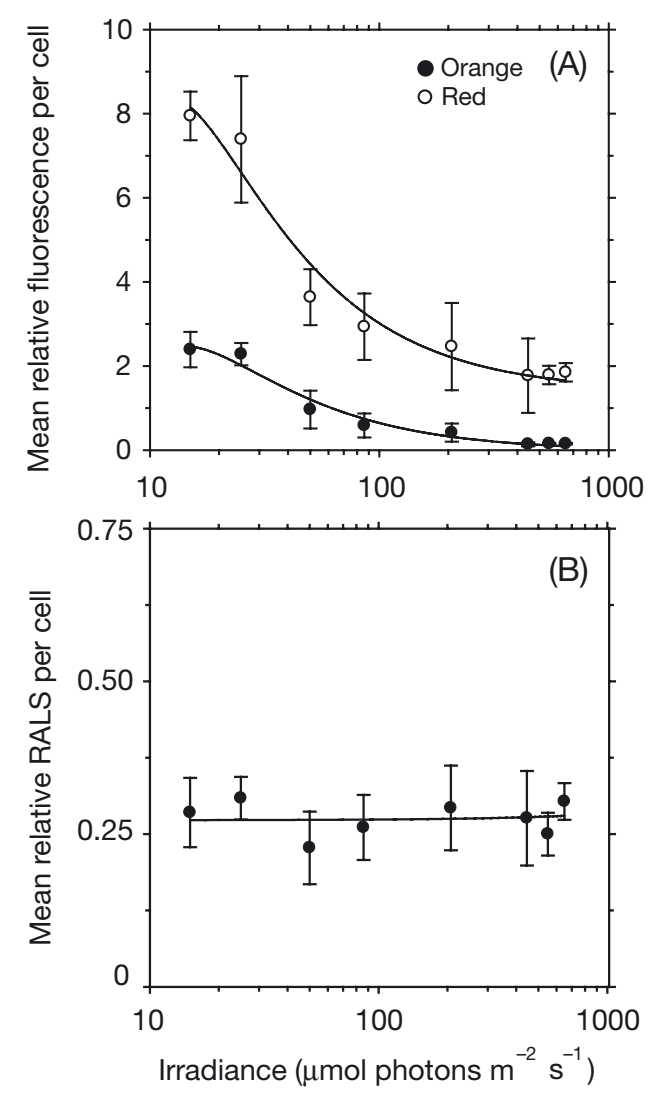

Fig. 1. Synechococcus sp. WH8102. Flow cytometric parameters as a function of growth irradiance in Synechococcus sp. WH8102. (A) Average red $(O)$ and orange $(\bullet$ fluorescence per cell and (B) average right angle light scatter (RALS) per cell. Values are relative to $0.95 \mu \mathrm{m}$ reference beads

correlation to $\mathrm{PE}$ content $\left(\mathrm{OF}=0.027[\mathrm{PE}]+0.144_{i} \mathrm{r}^{2}=\right.$ $0.76, \mathrm{n}=8$ ), probably due to some scatter in the PE data. In contrast, light scatter signals (RALS) did not vary significantly with growth irradiance (Fig. 1B). The average RALS value normalised to $0.95 \mu \mathrm{m}$ reference beads was $0.27 \pm 0.06$.

\section{Absorption properties of whole cells and pigment extracts}

Fig. 2 shows the light-induced variations in the absorption properties of whole cells and methanolic extracts from Synechococcus sp. WH8102. In vivo absorption spectra indicate that this cyanobacterium absorbs light efficiently in the blue region, with 2 prominent peaks at $440 \mathrm{~nm}$ (chl a) and $492 \mathrm{~nm}$ (mainly due to PUB and carotenoids) when grown under irradiances $\leq 25 \mu \mathrm{mol}$ photons $\mathrm{m}^{-2} \mathrm{~s}^{-1}$. Under the latter light conditions, the PUB peak is about twice higher than the PEB peak (at $543 \mathrm{~nm}$; Fig. 2A). Thus, Synechococcus sp.
WH8102 has a very high PUB:PEB ratio. The aspect of in vivo absorption spectra normalised to the red peak varied tremendously in the 400 to $550 \mathrm{~nm}$ part, as a result of the dramatic light-induced changes in pigmentation mentioned above. Indeed, as light increased, the relative contributions of chl a and PEB decreased tremendously, whereas that of zeaxanthin became more and more preponderant. This dominance of the contribution of zeaxanthin at high light appears clearly when looking at spectra of methanolic extracts at 445 or $650 \mu \mathrm{mol}$ photons $\mathrm{m}^{-2} \mathrm{~s}^{-1}$ (Fig. 2B), which in their blue part closely match with the absorption spectrum of pure zeaxanthin (Fig. 2B, insert). The contribution of PCB $\left(\lambda_{\max }=630 \mathrm{~nm}\right)$ is hard to differentiate from that of the absorption band of chl $a$ in the same region. Pigment absorbance indexes (see 'Materials and methods') can be used to approximate the contents of major pigments (Fig. 3A). $I_{\mathrm{chl}}$ and $I_{\mathrm{PEB}}$ clearly followed a similar pattern with a 75 and $73 \%$ decrease, respectively, from 15 to $650 \mu \mathrm{mol}$ photons $\mathrm{m}^{-2} \mathrm{~s}^{-1}$, whereas for $I_{\mathrm{PUB}}$, the apparent decrease was lower $(45 \%)$ because of the counter-

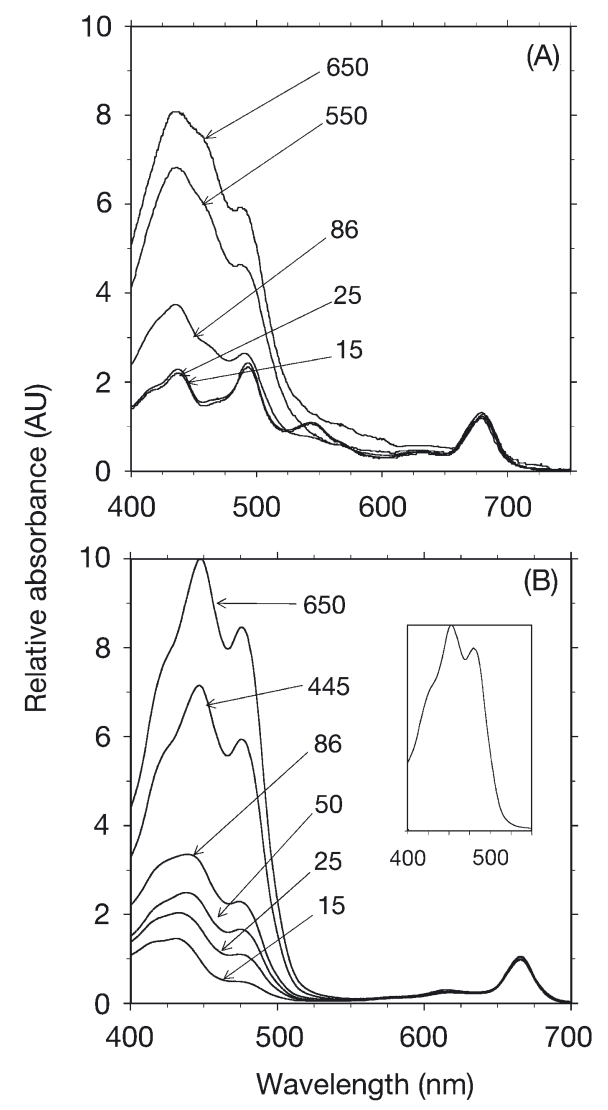

Fig. 2. Synechococcus sp. WH8102. Absorption spectra of (A) whole cells and (B) methanolic extracts of cells grown over a light gradient. Insert: spectrum of pure zeaxanthin in methanol. Numbers indicate irradiances in $\mu \mathrm{mol}$ photons $\mathrm{m}^{-2}$ $\mathrm{s}^{-1}$. Spectra were equalised at $750 \mathrm{~nm}$ and normalised at the red chl a maximum (ca. $680 \mathrm{~nm})$. AU = arbitrary units 
acting influence of carotenoids (Fig. 2A). Thus, when carotenoids become abundant in the cell, the PUB absorbance index is no more relevant. Fig. 3B shows the relative light-induced changes in absorbance ratio at wavelengths corresponding to the 2 major chl a peaks ( $B: R$ ratio). The $B: R$ ratio displayed a linear increase with growth irradiance with a 4 -fold increase between 15 and $650 \mu \mathrm{mol}$ photons $\mathrm{m}^{-2} \mathrm{~s}^{-1}$.

There was no drastic alteration of the in vivo absorption spectrum when Synechococcus cells were grown under white, red or green light at $25 \mu \mathrm{mol}$ photons $\mathrm{m}^{-2}$ $\mathrm{s}^{-1}$ (data not shown). However, a slight decrease in the relative contribution of $\mathrm{PE}$ and chl a could be seen under blue-green light, comparable to that resulting from a slight increase in growth irradiance.

\section{Absorption spectra of PBS-enriched fractions}

Absorption spectra of thylakoid-free fractions of soluble proteins containing intact PBS in $0.75 \mathrm{M}$ phos-
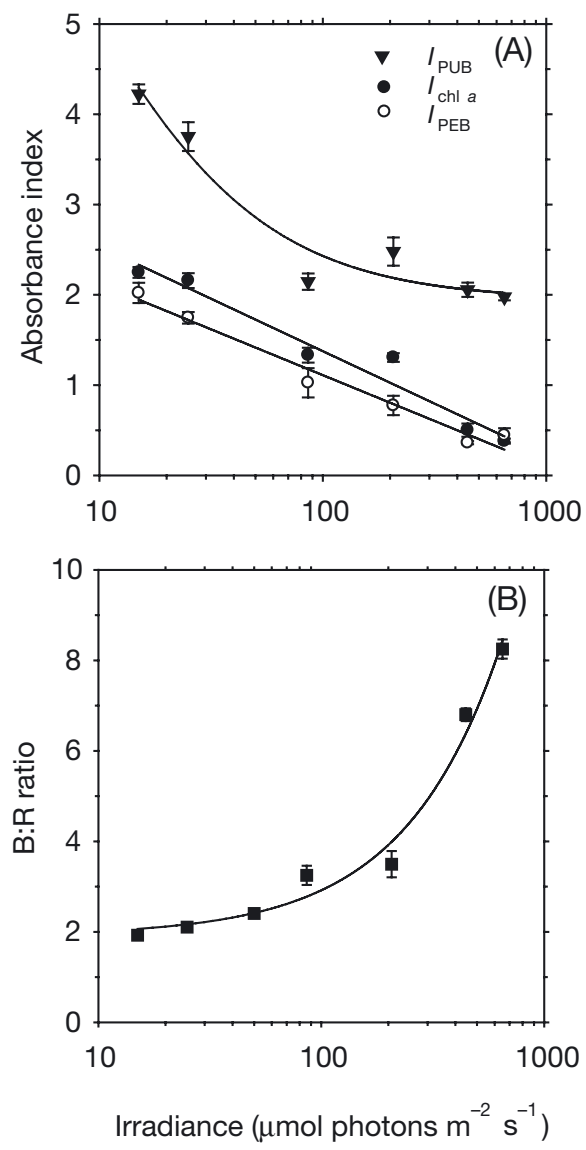

Fig. 3. Synechococcus sp. WH8102. (A) PUB, PEB and chl a absorbance indexes ( $I_{\mathrm{PUB}}, I_{\mathrm{PEB}}$ and $\left.I_{\mathrm{chl}}\right)$ and (B) blue:red (B:R) ratio, as a function of growth irradiance in Synechococcus sp. WH8102 phate were performed in order to study the lightinduced changes in chromophore contents within the PBS (Fig. 4A). The PEB:PCB and PUB:PCB ratios both decreased by a factor of ca. 4-fold between 15 and $650 \mu \mathrm{mol}$ photons $\mathrm{m}^{-2} \mathrm{~s}^{-1}$ (Fig. 4A,B). Interestingly, the PEB makes a broad band comprising 2 major components at ca. 538 and $561 \mathrm{~nm}$. Interpretation of these peaks is somewhat complex. Indeed, it has been shown in Synechococcus sp. WH8103 that the PEB associated to PEII has an absorption maximum at $543 \mathrm{~nm}$, to PEI at 550 to $563 \mathrm{~nm}$ (Ong \& Glazer 1991) and to PCII at 533 and $554 \mathrm{~nm}$ (Ong \& Glazer 1987). It is reasonable to assume that the PEB bound by PEII is the major contributor to the $538 \mathrm{~nm}$ component, even if PEI should also contribute to it to a lesser extent. The $561 \mathrm{~nm}$ component must integrate contributions of both PEI and PCII (Ong \& Glazer 1987, 1991). Thus, the strong relative decrease in the $538 \mathrm{~nm}$ band at high light with
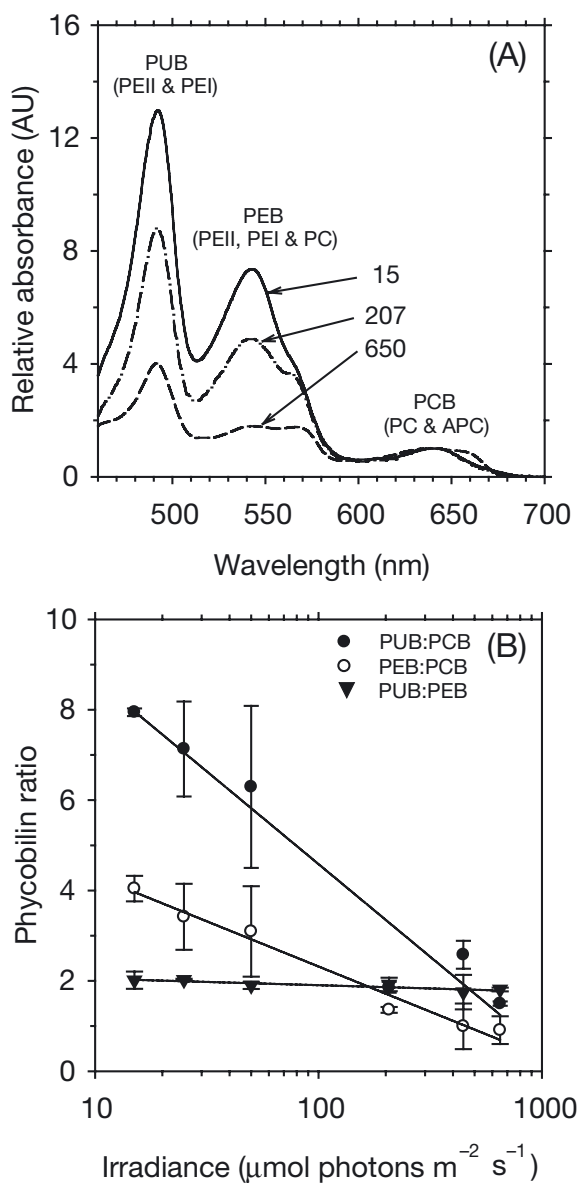

Fig. 4. Synechococcus sp. WH8102. (A) Absorption spectra of PBS-enriched fractions of cells grown at 15, 207 and $650 \mu \mathrm{mol}$ photons $\mathrm{m}^{-2} \mathrm{~s}^{-1}$ normalised at the PCB maximum $(640 \mathrm{~nm})$. The phycobilins and the PBP to which they are bound are indicated. (B) Variations of the PUB:PCB, PEB:PCB and PUB:PEB absorption ratios over a range of growth irradiances. $\mathrm{AU}=$ arbitrary units 
regard to the $561 \mathrm{~nm}$ band likely indicates a sharp decrease in the PEII content within the PBS rods. The PCB, which is associated to both PCII and APC, exhibited a maximum at $640 \mathrm{~nm}$ at all irradiances tested.

PUB:PEB ratios were computed from these absorption spectra (Fig. 4B). Contrary to those derived from fluorescence excitation spectra (see below), they did not show a statistically significant trend with irradiance (PUB: $\mathrm{PEB}_{\text {avg }}=1.78 \pm 0.11, \mathrm{n}=12$ ).

\section{Fluorescence properties}

Fluorescence emission spectra of whole Synechococcus sp. WH8102 cells at room temperature with excitation at $492 \mathrm{~nm}$ (i.e. in the maximum absorption band of PUB) showed 2 main peaks at 566 to $572 \mathrm{~nm}$ and $650 \mathrm{~nm}$ (Fig. 5A), attributable to $\mathrm{PE}$ and $\mathrm{PC}$, respectively (Ong \& Glazer 1991). A third maximum at $680 \mathrm{~nm}$
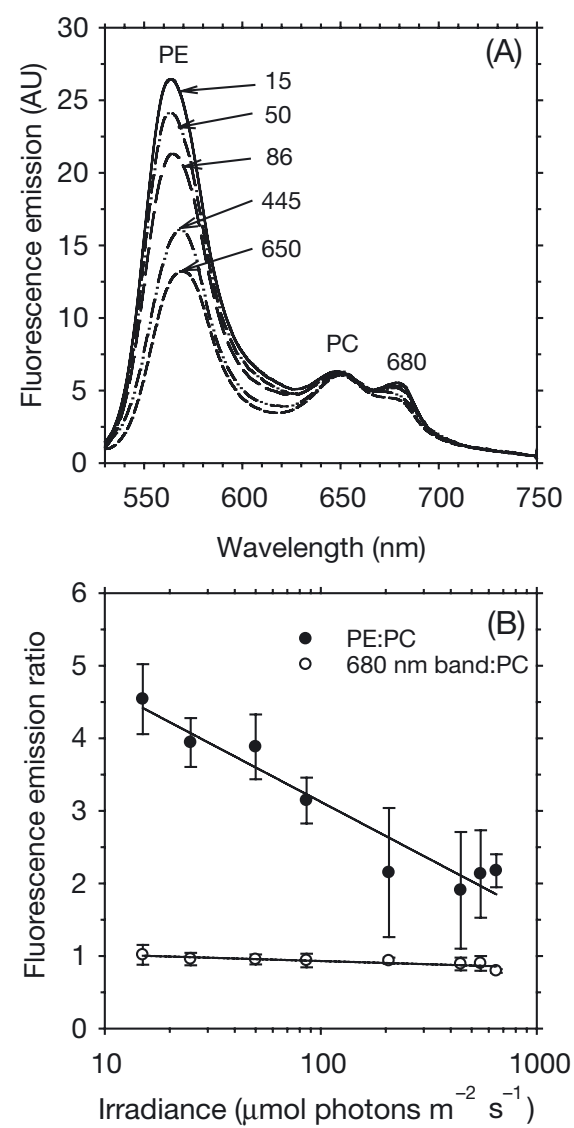

Fig. 5. Synechococcus sp. WH8102. (A) Fluorescence emission spectra with excitation at $492 \mathrm{~nm}$ of whole cells and (B) variations of the PE:PC and $680 \mathrm{~nm}$ band:PC fluorescence emission ratios of cells grown under several irradiances. Spectra shown in (A) were recorded at room temperature and normalised at the $\mathrm{PC}$ maximum (ca. $650 \mathrm{~nm}$ ). AU = arbitrary units most likely originates from a chl a terminal energy acceptor (Hassidim et al. 1997), although APC forms acting as terminal acceptors in the PBS are also expected to fluoresce in this region. The shift in the position of the PE peak from $566 \pm 0.6 \mathrm{~nm}$ at low light to $572 \pm$ $1.0 \mathrm{~nm}$ at the highest growth irradiance (Fig. 5A) indicated a change in the relative proportion of PEI and PEII (see 'Discussion'). With increasing growth irradiances, the relative height of the PE band dramatically decreased relative to the PC peak. Similar variations of the fluorescence emission peaks were observed at $77^{\circ} \mathrm{K}$ (data not shown). The PE:PC peak ratio decreased from $4.54 \pm 0.48$ at $15 \mu \mathrm{mol}$ photons $\mathrm{m}^{-2} \mathrm{~s}^{-1}$ to $2.17 \pm 0.23$ at $650 \mu \mathrm{mol}$ photons $\mathrm{m}^{-2} \mathrm{~s}^{-1}$ (Fig. 5B). The ratio of the $680 \mathrm{~nm}$ fluorescence emission band to PC emission maximum (680:PC) exhibited a slight decrease with increasing growth irradiances (Fig. 5B). This suggests that at high light, PBSs might be partially disconnected
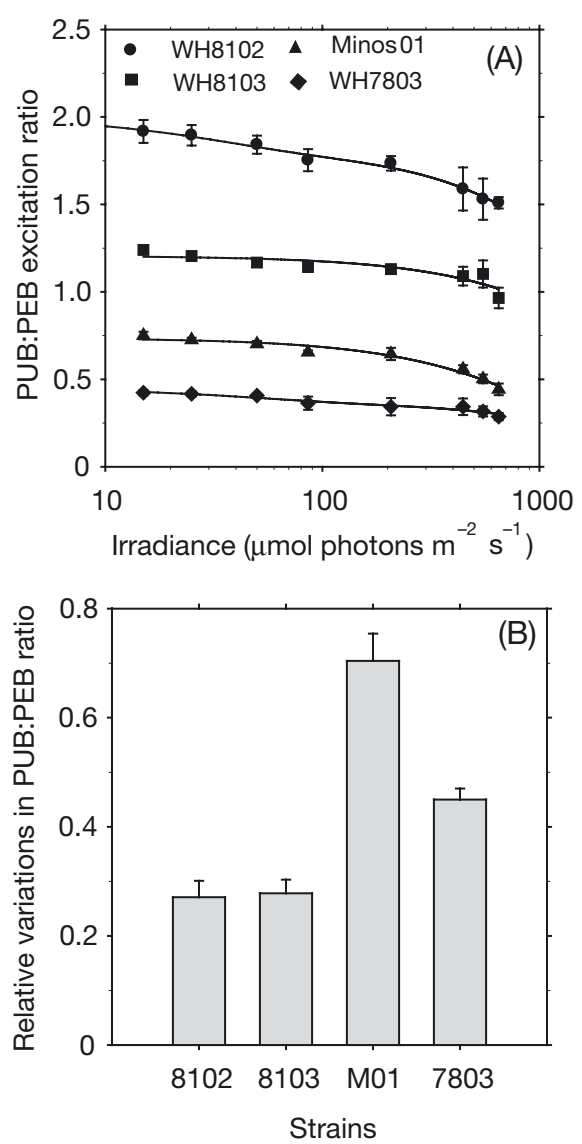

Fig. 6. Synechococcus strains. (A) Light-induced variations of the Exc 492:543 ratio (i.e. PUB:PEB ratio) for 4 marine Synechococcus strains grown under different irradiances: WH8102, WH8103, WH7803 and Minos01 and (B) relative variations in the ratios of Exc 492:543 at 15 and $650 \mu \mathrm{mol}$ photons $\mathrm{m}^{-2} \mathrm{~s}^{-1}$, calculated as [Exc 492:543 (15 $\mathrm{mmol}$ photons $\mathrm{m}^{-2} \mathrm{~s}^{-1}$ ) - Exc 492:543 (650 $\mu \mathrm{mol}$ photons $\left.\left.\mathrm{m}^{-2} \mathrm{~s}^{-1}\right)\right] /\left[\right.$ Exc 492:543 $\left(15 \mu \mathrm{mol}\right.$ photons $\left.\mathrm{m}^{-2} \mathrm{~s}^{-1}\right)$ ] 
from RCIIs. However, this decrease is hard to unambiguously interpret since it is not possible to discriminate between the relative contribution to the $680 \mathrm{~nm}$ band of the fluorescence associated to chl a forms of PSII from that linked to the terminal acceptors of PBS.

In vivo fluorescence excitation spectra of the PE emission band showed 2 peaks at 492 and $543 \mathrm{~nm}$ due to PUB and PEB, respectively (data not shown; see e.g. Lantoine \& Neveux 1997). The PUB:PEB ratio of Synechococcus sp. WH8102 cells, as determined from the ratio of excitation peak maxima at 492 and $543 \mathrm{~nm}$ (Exc 492:543), varied slightly from 1.95 at low light down to 1.5 at high light (Fig. 6A). For comparison, we also followed the variations of the PUB:PEB ratio in 3 other strains: WH7803, WH8103 and Minos01. All strains showed a small but significant decrease in this ratio with increasing irradiance, with the high PUB strains WH8102 and WH8103 displaying the lowest relative change with irradiance (Fig. 6B). It is noteworthy that for all strains the decrease was more marked at the 3 highest irradiances tested than over the rest of the gradient.

Growing Synechococcus spp. strains under different light qualities, but at a fixed irradiance, did not induce any clear alterations of the PUB:PEB ratio of the cells, except that under blue-green light, Exc 492:543 was always slightly lower than under other light colours in all strains (data not shown).

\section{DISCUSSION}

\section{Photophysiology and niche adaptation}

Although it is routinely maintained at 20 to $30 \mu \mathrm{mol}$ photons $\mathrm{m}^{-2} \mathrm{~s}^{-1}$ in culture (see e.g. Brahamsha 1996a,b), Synechococcus sp. WH8102, which has one of the highest PUB:PEB ratios ever reported among isolates in culture (1.95 at low light; Waterbury et al. 1986, Toledo et al. 1999, Fuller et al. 2003), can in fact be grown over a wide range of growth irradiance. Its compensation irradiance for growth, i.e. the light level at which no growth occurs $\left(I_{\text {comp }}\right.$ calculated from data in Table 1), was as low as $2 \mu \mathrm{mol}$ photons $\mathrm{m}^{-2} \mathrm{~s}^{-1}$, and its growth rate reached a maximum at $207 \mu \mathrm{mol}$ photons $\mathrm{m}^{-2} \mathrm{~s}^{-1}\left(\mu=1.13 \pm 0.02 \mathrm{~d}^{-1}\right)$ and remained quite high $\left(\mu>0.85 \mathrm{~d}^{-1}\right)$ up to $650 \mu \mathrm{mol}$ photons $\mathrm{m}^{-2} \mathrm{~s}^{-1}$. Furthermore, Synechococcus sp. WH8102 grows at higher rates under blue-green than white or green light, and it has an even lower $I_{\text {comp }}$ under those wavelengths (ca. 450 to $475 \mathrm{~nm}$ ) that penetrate the deepest in oligotrophic waters (Morel 1978).

Synechococcus sp. WH7803, which has a PUB:PEB ratio of only 0.40 at low light (Fig. 6A), has previously been shown to be able to grow under continuous irradiances up to $2000 \mu \mathrm{mol}$ photons $\mathrm{m}^{-2} \mathrm{~s}^{-1}$ (Kana \& Glibert 1987a).
Extrapolation of the growth curve of WH8102 towards higher irradiances suggests that the growth rate of this strain would be significantly lowered at such a high irradiance. This is confirmed by failed attempts to grow this strain at $1000 \mu \mathrm{mol}$ photons $\mathrm{m}^{-2} \mathrm{~s}^{-1}$ continuous white light (data not shown). Thus, this high PUB strain seems to be more sensitive to very high photon fluxes than the low PUB strain WH7803. In contrast, WH8102 might perform better at very low light since it has a lower compensation irradiance for growth than WH7803 $\left(I_{\text {comp }} \approx 2\right.$ and $13 \mu \mathrm{mol}$ photons $\mathrm{m}^{-2} \mathrm{~s}^{-1}$, respectively; the latter value was estimated from Fig. 1 in Kana \& Glibert 1987a). However, in our culture conditions, WH7803 still grew well at $15 \mu \mathrm{mol}$ photons $\mathrm{m}^{-2} \mathrm{~s}^{-1}$ and its $I_{\text {comp }}$ was probably below $10 \mu \mathrm{mol}$ photons $\mathrm{m}^{-2} \mathrm{~s}^{-1}$.

The compensation irradiance for growth of Synechococcus sp. WH8102 is somehow intermediate between that of the low light adapted strain Prochlorococcus marinus SS120 ( $I_{\text {comp }}=1.4 \pm 1.0 \mu \mathrm{mol}$ photons $\left.\mathrm{m}^{-2} \mathrm{~s}^{-1}\right)$ and that of the high light adapted Prochlorococcus sp. strain MED4 $\left(I_{\text {comp }}=4.62 \pm 2.0 \mu \mathrm{mol}\right.$ photons $\left.\mathrm{m}^{-2} \mathrm{~s}^{-1}\right)$, considering that the latter were grown under a $14: 10 \mathrm{~h}$ light:dark cycle (Moore et al. 1995). However, growth of SS120 is completely inhibited at $200 \mu \mathrm{mol}$ photons $\mathrm{m}^{-2}$ $\mathrm{s}^{-1}$, which is the optimal growth irradiance $\left(I_{\max }\right)$ for WH8102, and MED4 has an $I_{\max }$ at only $90 \pm 1.0 \mu \mathrm{mol}$ photons $\mathrm{m}^{-2} \mathrm{~s}^{-1}$ and its growth rate is significantly lowered at $450 \mu \mathrm{mol}$ photons $\mathrm{m}^{-2} \mathrm{~s}^{-1}$ (Moore et al. 1995). Thus, Synechococcus sp. WH8102 appears to be adapted to a wider light gradient than individual Prochlorococcus isolates. Interestingly, comparison of the genomes of Synechococcus sp. WH8102 and 2 Prochlorococcus spp. strains (MED4 and MIT9313) also led Palenik et al. (2003) to conclude that Synechococcus was more of a generalist, based on its more complete set of genes for a number of key metabolic functions.

The maximum growth rate of Synechococcus sp. WH8102 $\left(\mu_{\max }=1.13 \pm 0.02 \mathrm{~d}^{-1}\right)$ is significantly higher than that of Prochlorococcus SS120 and MED4 $\left(\mu_{\max }=\right.$ 0.53 and $0.63 \mathrm{~d}^{-1}$, respectively) but compares well with that of the high PUB Synechococcus sp. strain WH8103 $\left(\mu_{\max }=1.0 \pm 0.1 \mathrm{~d}^{-1}\right.$; Moore et al. 1995). However, the low PUB strain WH7803 grows almost twice as fast $\left(\mu_{\max }=1.87 \mathrm{~d}^{-1}\right.$ at 22 to $23^{\circ} \mathrm{C}$; Kana \& Glibert 1987a). Comparing the estimated growth rates of 'dim' (i.e. low PUB) and 'bright' (i.e. high PUB) Synechococcus spp. at different depths in the Arabian Sea, Liu et al. (1998) also observed that at 2 stations during the early NE monsoon, 'dim' cells in the upper layer had a higher growth rate than 'bright' cells (1.5 to $1.9 \mathrm{~d}^{-1}$ and 0.9 to $1.1 \mathrm{~d}^{-1}$, respectively; their Fig. 7 ). However, rates were not significantly different (ranging from 0.6 to $2.0 \mathrm{~d}^{-1}$ ) for the 2 cell types during the late SW monsoon, so this observation apparently cannot be generalised. 


\section{Light-induced changes in the structure of the photosynthetic apparatus}

Synechococcus sp. WH8102 acclimates to changes in growth irradiances by drastic variations in the relative content of chl $a$, $\beta$-carotene and PBPs, whereas zeaxanthin remains at a quasi constant level whatever the irradiance. The contrasting behaviour of these pigments translates into dramatic modifications of the shape of absorption spectra between low and high light (Fig. 2). The apparent dominance of the zeaxanthin contribution in the blue region of these spectra at high light as well as the strong light-induced increase in the zeaxanthin:chl a ratio (Table 1 ) raise questions about the photoprotective role of this xanthophyll. Constancy of the zeaxanthin content has been reported for other marine Synechococcus strains and was generally interpreted as an argument for a major localisation of this pigment in membranes other than thylakoids (Kana et al. 1988, Moore et al. 1995, Lutz et al. 2001). In freshwater cyanobacteria, the bulk of zeaxanthin has been reported to be located within the cell envelope (plasma and/or outer membrane; Murata \& Omata 1988, Reddy et al. 1993, Wu \& Krogmann 1997), and this is possibly the case in marine Synechococcus as well. However, in contrast to what is observed, e.g. in the freshwater Synechococcus sp. PCC7942 (Reddy et al. 1993, Masamoto et al. 1999), there is no apparent active accumulation of this zeaxanthin pool in marine Synechococcus. This seemingly 'passive' zeaxanthin pool may still have a limited role as a 'sunscreen' in these cells at high light, but only by virtue of the sharp reduction of thylakoid surfaces at high light, as observed in Synechococcus sp. WH7803 by Kana \& Glibert (1987a). In photosynthetic eukaryotes, zeaxanthin generated in the thylakoid membranes via the xanthophyll cycle operation, is known to be involved in the de-excitation of singlet or triplet chlorophylls and in the elimination of noxious activated oxygen species generated by the photooxidation of chlorophylls (see e.g. Young \& Britton 1993, Niyogi 1999). A zeaxanthin pool located within the thylakoids is therefore much more critical for photoprotection processes than is a zeaxanthin pool remote from the photosynthetic pigment-protein complexes. The preliminary characterisation of thylakoid fractions from Synechococcus sp. WH8102 suggests that there is indeed a pool of zeaxanthin associated with thylakoids (C. Six unpubl.). It is not unlikely that this thylakoid pool constitutes a significant part of the total zeaxanthin pool in marine Synechococcus, but remains globally constant whatever the light level. With the sharp reduction in the number of thylakoid rows at high light (Kana \& Glibert 1987a), the number of zeaxanthin molecules per thylakoid surface would significantly increase; and therefore could have an active photoprotective role after their redeployment over the remaining membranes. Confirmation of this role awaits the construction and characterisation of knock-out mutants deprived in their ability to synthesise zeaxanthin, but our trials to obtain such mutants have failed to date, possibly because this mutation is lethal (data not shown).

The strong decrease in the PE content per cell (Table 1) as well as in PEB and PUB absorbance indexes (Fig. 3A) at high light is attributable not only to the decrease in number of PBS per cell, mainly due to the reduction of the total thylakoidal surface, but also to structural changes within the PBSs themselves. Indeed, both fluorescence emission spectra of whole cells (Fig. 5) and absorption spectra of PBSs (Fig. 4) show that the $\mathrm{PE}$ amount sharply decreases with regard to $\mathrm{PC}$, indicating that the $\mathrm{PE}$ rod extremities are shortened in response to high light. A similar response was reported for the PE-rich PBSs of the red alga Rhodella violacea (Bernard et al. 1996). A small but significant red shift in the position of the PE fluorescence emission peak (from 566 to 572 nm, Fig. 6) further suggests a progressive reduction in the PEII:PEI ratio. Indeed, PEI and PEII exhibit distinct fluorescence emission wavelengths at 573 and $565 \mathrm{~nm}$, respectively (Ong \& Glazer 1991). A comparable red shift (from 565 to $570 \mathrm{~nm}$ ) had previously been observed at an oligotrophic station of the tropical NE Atlantic between depth and surface Synechococcus spp. (Lantoine \& Neveux 1997). This shift suggests that rod extremities constituted by PEII molecules are specifically affected during the PBS rod shortening at high light. Presence of the PUB-richer PEII form at the most distal part of PBS rods is consistent with the fact that the energy flow is assumed to go from the PUB to the PEB chromophores (Glazer 1989). Another interesting observation is the small but significant reduction of the PUB:PEB excitation ratio (Exc 492:543 ratio) at high light that we observed with 4 different Synechococcus spp. strains (Fig. 6), a phenomenon which may also be attributed to the reduction in PEII:PEI ratio. Lantoine \& Neveux (1997) observed such a decrease in the Exc 495:545 ratio with depth, but only at nutrient-rich stations where there was co-occurrence of high and low PUB strains, but not at an offshore station dominated by high PUB genotypes at all depths. We show here that this phenomenon does occur in high PUB strains, but that the relative variations of PUB:PEB are fewer than in low PUB strains (Fig. 6B), which may explain why this phenomenon has not been seen to date for high PUB populations in the field. We attribute the lower variation of the PUB:PEB ratio in high PUB strains in part to the fact that PEI in these strains may be richer in PUB (Ong \& Glazer 1991). Hence, in absorption spectra, contribution of PEB associated to 
PC may interfere with that of the PEB associated to PEs (Fig. 6) and this could explain why we did not detect any significant light-induced variations of the PUB:PEB ratios derived from absorption measurements (Fig. 4B).

\section{Chromatic adaptation}

Many cyanobacteria have the ability to modulate the relative composition of their PBSs in response to changes in light climate (Grossman et al. 1994). This process is termed Group III chromatic adaptation (CA) when PC and PE concentrations show inverse variations after a shift from red to green light (or vice versa), or Group II CA when only PE concentrations vary following such a shift (Tandeau de Marsac \& Houmard 1988). Group III CA has been well characterised in freshwater cyanobacteria (see e.g. Campbell 1996, Allen \& Matthijs 1997), but it does not seem to occur in marine Synechococcus spp. strains. Hauschild et al. (1991) considered that Synechococcus sp. WH7803 exhibited a Group II CA since they measured a larger $\mathrm{PE}: \mathrm{C}$ ratio for cells grown under green rather than red light, but a similar PC:C ratio, despite a larger growth rate under the former condition. There is doubt however that, as these and other authors did, reliable PC concentrations can be derived from absorption measurements of whole marine Synechococcus spp. cells using Kursar \& Alberte's (1983) equations designed for quantifying C-PC from the red alga Neoagardhiella. Palenik (2001) reported another form of CA that could be called Group IV CA (B. Palenik pers. comm.) in 3 marine Synechococcus strains: when shifted from blue to either green or white light, these strains displayed a strong (ca. 2 to $3 \times$ ) decrease in PUB:PEB ratio (determined from their Exc 495:545 ratio). In contrast, no significant variations in the Exc 495:545 ratio was found over a (limited) white light gradient nor after submitting cells to different $\mathrm{N}$ stresses. Five other strains were screened by Palenik (2001), including WH8103, and did not show any blue light-induced increase in their Exc 495:545 ratio. In the present study, we have extended this study to WH8102, WH7803 and Minos01, and similarly none of them displayed Group IV CA (data not shown), although all strains exhibited a lower Exc 492:543 ratio at high compared to low light (see above). Growth under bluegreen light induced an increase in the growth rate of WH8102 (see 'Results') and a slight decrease in its Exc 492:543 ratio (from 1.85 to 1.80 ) relative to an equivalent white photon flux density. These variations seem to simply result from the fact that blue-green light is more efficient than white light for growth (due to strong absorption by PUB in the blue part of the visible spectrum), and therefore Synechococcus sp. WH8102 cells acclimate to a shift from white to blue light (at constant irradiance) as if it was a mere increase in white irradiance.

\section{Biomass indicators and flow cytometry}

One major interest of studying the photophysiology of Synechococcus isolates is to be able to estimate pigment and elemental composition of natural populations of these organisms. The good correlations found over the whole irradiance range between chl a content and RF and between PE content and OF suggest that these flow cytometric fluorescence signals can be used to estimate Synechococcus pigment contents in the field. Although correlation coefficients derived from culture isolates might actually be hard to apply to the heterogeneous Synechococcus spp. populations generally found in coastal and mesotrophic waters, this approach should at least be applicable for the quasi pure high PUB populations generally found in warm oligotrophic areas which have fairly homogeneous optical properties (Olson et al. 1990).

The good linearity between chl a content and RF is likely due to the weak package effect (i.e. self-shading) in Synechococcus spp. cells compared to largersized phytoplankton cells in which package effect may significantly affect this linearity (Sosik et al. 1989).

Both the RALS signal and cellular $\mathrm{C}$ and $\mathrm{N}$ contents of WH8102 appeared fairly constant with irradiance. The average $\mathrm{C}$ content $\left(279 \pm 84 \mathrm{fg} \mathrm{C} \mathrm{cell}^{-1}\right)$ is not statistically different from that recently determined for WH8103 by Bertilsson et al. (2003) (213 $\left.\pm 7 \mathrm{fg} \mathrm{C} \mathrm{cell}^{-1}\right)$ and Heldal et al. (2003) $\left(220 \pm 10\right.$ or $250 \pm 20 \mathrm{fg} \mathrm{C} \mathrm{cell}^{-1}$, depending on the culture medium) and also agrees well with that reported by Kana \& Glibert (1987a) for WH7803 (250 $\left.\pm 50 \mathrm{fg} \mathrm{C} \mathrm{cell}^{-1}\right)$.

In contrast to the latter authors, we observed no variations of the $\mathrm{C}: \mathrm{N}$ ratio with growth irradiance and the average $\mathrm{C}: \mathrm{N}$ ratio of WH8102 $(4.6 \pm 0.3)$ was at the lower range of those they measured in WH7803 (4.5 to $6.3)$, i.e. well below the Redfield ratio of 6.6 (Redfield 1958). Chemostat cultures of WH7803 showed even higher fluctuations of the C:N ratio, from ca. 10.0 in the most N-limited cultures to 5.1 in N-replete cultures (Liu et al. 1999). These chemostat experiments also demonstrated that low $\mathrm{N}$ conditions exert a similar effect of decreasing Synechococcus pigment content as does high light. The combined effects of low $\mathrm{N}$ and high light that Synechococcus cells experience in the upper mixed layer may therefore induce even smaller pigment contents as we observe here in our N-replete cultures grown at very high light. However, the N limitation could also have an effect on other cellular char- 
acteristics as well, such as the $\mathrm{C}: \mathrm{N}$ ratio. Thus, further lab studies which combine the 2 types of stress (low N, high light) would be required to determine the true limits of the pigment content and elemental composition of Synechococcus cells.

Acknowledgements. This work was supported by the EC programme MARGENES (QLRT 2001-01226) and the French programmes PROOF-BIOSOPE and PROOF-UVECO. C.S. is supported by a grant from the Ministère de la Recherche et des Nouvelles Technologies. We thank F. Legall and C. Carré for their help with culturing and medium preparation, and D. Marie for his advice on flow cytometry. E. Lecuyer and F. Gevaert are also warmly thanked for performing the CHN analyses.

\section{LITERATURE CITED}

Allen JF, Matthijs HCP (1997) Complementary adaptations, photosynthesis and phytochrome. Trends Plant Sci 2: $41-43$

Bernard C, Etienne AL, Thomas JC (1996) Synthesis and binding of phycoerythrin and its associated linkers to the phycobilisome in Rhodella violacea (Rhodophyta): compared effects of high light and translation inhibitors. J Phycol 32:265-271

Bertilsson S, Berglund O, Karl DM, Chisholm SW (2003) Elemental composition of marine Prochlorococcus and Synechococcus: implications for the ecological stoichiometry of the ocean. Limnol Oceanogr 48:1721-1731

Brahamsha B (1996a) A genetic manipulation system for oceanic cyanobacteria of the genus Synechococcus. Appl Environ Microbiol 62:1747-1751

Brahamsha B (1996b) An abundant cell-surface polypeptide is required for swimming by the non-flagellated marine cyanobacterium Synechococcus. Proc Natl Acad Sci USA 93:6504-6509

Bruyant F, Babin M, Sciandra A, Marie D and 8 others (2001) An axenic cyclostat of Prochlorococcus PCC 9511 with a simulator of natural light regimes. J Appl Phycol 13:135-142

Burkill PH, Leakey RJG, Owens NJP, Mantoura RFC (1993) Synechococcus and its importance to the microbial foodweb of the northwestern Indian Ocean. Deep-Sea Res Part II 40:773-782

Campbell D (1996) Complementary chromatic adaptation alters photosynthetic strategies in the cyanobacterium Calothrix. Microbiology 142:1255-1263

Campbell L, Iturriaga R (1988) Identification of Synechococcus spp. in the Sargasso Sea by immunofluorescence and fluorescence excitation spectroscopy performed on individual cells. Limnol Oceanogr 33:1196-1201

Duke CS, Cezeaux A, Mennes-Allen M (1989) Changes in polypeptide composition of Synechocystis sp. strain 6308 phycobilisomes induced by nitrogen starvation. J Bacteriol 171:1960-1966

Ferris MJ, Palenik B (1998) Niche adaptation in ocean cyanobacteria. Nature 396:226-228

Fuller NJ, Marie D, Partensky F, Vaulot D, Post AF, Scanlan DJ (2003) Clade-specific 16S rDNA oligonucleotides reveal the predominance of a single marine Synechococcus clade throughout a stratified water column in the Red Sea. Appl Environ Microbiol 69:2430-2443

Glazer AN (1985) Light harvesting by phycobilisomes. Annu Rev Biophys Biophys Chem 14:47-77

Glazer AN (1989) Light guides - directional energy transfer in a photosynthetic antenna. J Biol Chem 264:1-4

Grossman AR, Schaefer MR, Chiang GG, Collier JL (1994) The responses of cyanobacteria to environmental conditions: light and nutrients. In: Bryant DA (ed) The molecular biology of cyanobacteria. Kluwer Academic Publishers, Dordrecht, p 677-692

Hassidim M, Keren N, Ohad I, Reinhold L, Kaplan A (1997) Acclimation of Synechococcus strain WH7803 to ambient $\mathrm{CO}_{2}$ concentration and to elevated light intensity. J Phycol 33:811-817

Hauschild CA, McMurter HJG, Pick FR (1991) Effects of spectral quality on growth and pigmentation of picocyanobacteria. J Phycol 27:698-702

Heldal M, Scanlan DJ, Norland F, Thingstad F, Mann NH (2003) Elemental composition of single cells of various strains of marine Prochlorococcus and Synechococcus using X-ray microanalysis. Limnol Oceanogr 48:1732-1743

Herdman M, Castenholz RW, Waterbury JB, Rippka R (2001) Form-genus XIII. Synechococcus. In: Boone DR, Castenholz RW (eds) Bergey's manual of systematic bacteriology, Vol 1. Springer-Verlag, New York, p 508-512

Jiao N, Yang Y, Koshikawa H, Watanabe M (2002) Influence of hydrographic conditions on picoplankton distribution in the East China Sea. Aquat Microb Ecol 30:37-48

Kana TM, Glibert PM (1987a) Effect of irradiances up to 2000 $\mu \mathrm{E} \mathrm{m}^{-2} \mathrm{~s}^{-1}$ on marine Synechococcus WH7803I. Growth, pigmentation, and cell composition. Deep-Sea Res 34:479-485

Kana TM, Glibert PM (1987b) Effect of irradiances up to 2000 $\mu \mathrm{E} \mathrm{m}^{-2} \mathrm{~s}^{-1}$ on marine Synechococcus WH7803II. Photosynthetic responses mechanisms. Deep-Sea Res 34:497-516

Kana TM, Glibert PM, Goericke R, Welschmeyer NA (1988) Zeaxanthin and beta-carotene in Synechococcus WH7803 respond differently to irradiance. Limnol Oceanogr 33: 1623-1627

Kursar TA, Alberte RS (1983) Photosynthetic unit organization in a red alga. Plant Physiol 72:409-414

Lantoine F, Neveux J (1997) Spatial and seasonal variations in abundance and spectral characteristics of phycoerythrins in the tropical northeastern Atlantic Ocean. Deep-Sea Res I 44:223-246

Lee S, Fuhrman J (1987) Relationships between biovolume and biomass of naturally derived marine bacterioplankton. Appl Environ Microbiol 53:1298-1303

Liu H, Campbell L, Landry MR, Nolla HA, Brown SL, Constantinou J (1998) Prochlorococcus and Synechococcus growth rates and contributions to production in the Arabian Sea during the 1995 Southwest and Northeast Monsoons. Deep-Sea Res II 45:2327-2352

Liu HB, Bidigare RR, Laws E, Landry MR, Campbell L (1999) Cell cycle and physiological characteristics of Synechococcus (WH7803) in chemostat culture. Mar Ecol Prog Ser 189:17-25

Liu HB, Suzukil K, Minami C, Saino T, Watanabe M (2002) Picoplankton community structure in the subarctic Pacific Ocean and the Bering Sea during summer 1999. Mar Ecol Prog Ser 237:1-14

Lutz VA, Sathyendaranath S, Head EJH, Li WKW (2001) Changes in the in vivo absorption and fluorescence excitation spectra with growth irradiance in three species of phytoplankton. J Plankton Res 23:555-569

Marie D, Brussaard C, Partensky F, Vaulot D (1999) Flow cytometric analysis of phytoplankton, bacteria and viruses. In: Sons JW (ed) Current protocols in cytometry. International Society for Analytical Cytology, John Wiley \& Sons, New York, Unit 11.11, p 1-15 
Masamoto K, Zsiros O, Gombos Z (1999) Accumulation of zeaxanthin in cytoplasmic membranes of the cyanobacterium Synechococcus sp. strain PCC7942 grown under high light condition. J Plant Physiol 155:136-138

Mitchell GA, Kiefer DA (1988) Chlorophyll a specific absorption and fluorescence excitation spectra for light-limited phytoplankton. Deep-Sea Res 35:639-663

Moore LR, Chisholm SW (1999) Photophysiology of the marine cyanobacterium Prochlorococcus: Ecotypic differences among cultured isolates. Limnol Oceanogr 44:628-638

Moore LR, Goericke R, Chisholm SW (1995) Comparative physiology of Synechococcus and Prochlorococcus: influence of light and temperature on growth, pigments, fluorescence and absorptive properties. Mar Ecol Prog Ser 116:259-275

Moore LR, Rocap G, Chisholm SW (1998) Physiology and molecular phylogeny of coexisting Prochlorococcus ecotypes. Nature 393:464-467

Morel (1978) Available, usable, and stored radiant energy in relation to marine photosynthesis. Deep-Sea Res 25: 673-688

Murata N, Omata T (1988) Isolation of cyanobacterial plasma membranes. Methods Enzymol 167:245-251

Niyogi KK (1999) Photoprotection revisited: genetic and molecular approaches. Annu Rev Plant Physiol Plant Mol Biol 50:333-359

Olson RJ, Chisholm SW, Zettler ER, Armbrust EV (1988) Analysis of Synechococcus pigment types in the sea using single and dual beam flow cytometry. Deep-Sea Res 35: $425-440$

Olson RJ, Zettler ER, Armbrust EV, Chisholm SW (1990) Pigment, size and distribution of Synechococcus in the North Atlantic and Pacific oceans. Limnol Oceanogr 35:45-58

Ong LJ, Glazer AN (1987) R-phycocyanin II, a new phycocyanin occurring in marine Synechococcus species. J Biol Chem 262:6323-6327

Ong LJ, Glazer AN (1991) Phycoerythrin of marine unicellular cyanobacteria. I. Bilin types and locations and energy transfer pathways in Synechococcus spp. J Biol Chem 266: 9515-9527

Ong LJ, Glazer AN, Waterbury JB (1984) An unusual phycoerythrin from a marine cyanobacterium. Science 224:80-83

Palenik B (2001) Chromatic adaptation in marine Synechococcus strains. Appl Environ Microbiol 67:991-994

Palenik B, Brahamsha B, Larimer F, Land M and 11 others (2003) The genome of a motile marine Synechococcus. Nature 424:1037-1042

Partensky F, Blanchot J, Lantoine F, Neveux J, Marie D (1996) Vertical structure of picophytoplankton at different trophic sites of the tropical northeastern Atlantic Ocean. Deep-Sea Res I 43:1191-1213

Partensky F, Blanchot J, Vaulot D (1999a) Differential distribution and ecology of Prochlorococcus and Synechococcus in oceanic waters: a review. In: Charpy L, Larkum AWD (eds) Marine cyanobacteria. Musée Océanographique, Monaco, p 457-475

Partensky F, Hess WR, Vaulot D (1999b) Prochlorococcus, a marine photosynthetic prokaryote of global significance. Microbiol Mol Biol Rev 63:106-127

Reddy KJ, Bullerjahn GS, Sherman LA (1993) Characteristics of membrane-associated carotenoid-binding proteins in cyanobacteria and prochlorophytes. Methods Enzymol 214:390-401

Redfield AC (1958) The biological control of chemical factors in the environment. Am Sci 46:205-221

Scanlan DJ (2003) Physiological diversity and niche adaptation in marine Synechococcus. Adv Microb Physiol 47:1-64

Shalapyonok A, Olson RJ, Shalapyonok LS (2001) Arabian Sea phytoplankton during Southwest and Northeast monsoons 1995: composition, size structure and biomass from individual cell properties measured by flow cytometry. Deep-Sea Res II 48:1231-1261

Sherry ND, Wood AM (2001) Phycoerythrin-containing picocyanobacteria in the Arabian Sea in February 1995: diel patterns, spatial variability, and growth rates. Deep-Sea Res II 48:1263-1283

Sieracki ME, Haugen EM, Cucci TL (1995) Overestimation of bacteria in the Sargasso Sea: direct evidence by flow and imaging cytometry. Deep-Sea Res Part I 42:1399-1409

Sosik HM, Olson RJ, Chisholm SW (1989) Chlorophyll fluorescence from single cells: interpretation of flow cytometric signals. Limnol Oceanogr 34:1749-1761

Swanson RV, Ong LJ, Wilbanks SM, Glazer AN (1991) Phycoerythrins of marine unicellular cyanobacteria. II. Characterization of phycobiliproteins with unusually high phycourobilin. J Biol Chem 266:9528-9534

Tandeau de Marsac N, Houmard J (1988) Complementary chromatic adaptation: physiological conditions and action spectra. Methods Enzymol 167:318-328

Toledo G, Palenik B (2003) A Synechococcus serotype is found preferentially in surface marine waters. Limnol Oceanogr 48:1744-1755

Toledo G, Palenik B, Brahamsha B (1999) Swimming marine Synechococcus strains with widely different photosynthetic pigment ratios form a monophyletic group. Appl Environ Microbiol 65:5247-5251

Urbach E, Scanlan DJ, Distel DL, Waterbury JB, Chisholm SW (1998) Rapid diversification of marine picophytoplankton with dissimilar light-harvesting structures inferred from sequences of Prochlorococcus and Synechococcus (Cyanobacteria). J Mol Evol 46:188-201

Vaulot D (1989) CYTOPC: processing software for flow cytometric data. Signal Noise 2:8

Waterbury JB, Watson SW, Valois FW, Franks DG (1986) Biological and ecological characterization of the marine unicellular cyanobacterium Synechococcus. Can J Fish Aquat Sci Bull (Spec Iss) 214:71-120

West NJ, Scanlan DJ (1999) Niche-partitioning of Prochlorococcus populations in a stratified water column in the eastern north Atlantic ocean. Appl Environ Microbiol 65: $2585-2591$

Wilbanks SM, de Lorimier R, Glazer AN (1991) Phycoerythrins of marine unicellular cyanobacteria. III. Sequence of a class II phycoerythrin. J Biol Chem 266:9535-9539

Wood AM, Phinney DA, Yentsch CS (1998) Water transparency and the distribution of spectrally distinct forms of phycoerythrin-containing organisms. Mar Ecol Prog Ser 162:25-31

Wood AM, Lipsen M, Coble P (1999) Fluorescence-based characterization of phycoerythrin-containing cyanobacterial communities in the Arabian Sea during the Northeast and early Southwest Monsoon (1994-1995). Deep-Sea Res II 46:1769-1790

Wright SW, Jeffrey SW (1997) High resolution HPLC system for chlorophylls and carotenoids of marine phytoplankton. In: Jeffrey SW, Mantoura RFC, Wright SW (eds) Phytoplankton pigments in oceanography: guidelines to modern methods. UNESCO, Paris, p 327-341

Wu YP, Krogmann DW (1997) The orange carotenoid protein of Synechocystis PCC 6803. Biochim Biophys Acta 1322:1-7

Young A, Britton G (1993) Carotenoids in photosynthesis. Chapman \& Hall, London

Submitted: May 26, 2003; Accepted: October 8, 2003

Proofs received from author(s): March 1, 2004 